\title{
Graft-versus-host disease after liver transplantation complicated by systemic aspergillosis with pancarditis
}

Joseph Romagnuolo MD FRCPC ${ }^{1}$, Laurence D Jewell MD FRCPC ${ }^{2}$, Norman M Kneteman MD FRCSC ${ }^{3}$, Vince G Bain MD FRCPC ${ }^{1}$

J Romagnuolo, LD Jewell, NM Kneteman, VG Bain. Graftversus-host disease after liver transplantation complicated by systemic aspergillosis with pancarditis. Can J Gastroenterol 2000;14(7):637-640. Acute graft-versus-host disease (GVHD) is a common complication after bone marrow transplantation, with characteristic rash and diarrhea being the most common features. After liver transplantation, however, this phenomenon is very rare. Most transplant patients are on a variety of medications, including immunosuppressants; therefore, the differential diagnosis of skin rash or diarrhea is broad. A 37-year-old man who underwent liver transplantation for primary biliary cirrhosis, and developed a rash and watery diarrhea, is presented. Skin and colonic biopsies confirmed acute GVHD. A pulse of intravenous steroids was given. The skin rash improved, but he developed pancytopenia. His course was complicated by central line infection, jugular and subclavian vein thrombosis, pseudomembranous colitis, recurrent bacteremia, cholestasis on total parenteral nutrition and cytomegalovirus infection. After the onset of pleuritic chest pain and clinical sepsis, spiral computed tomography scan of his chest and abdomen revealed septic infarcts in multiple organs. Despite empirical treatment with amphotericin B, he died of multiorgan dysfunction syndrome within $72 \mathrm{~h}$. Autopsy revealed systemic aspergillosis with pancarditis, endocardial vegetations, and septic pulmonary, splenic, hepatic and renal infarcts. The pathogenesis and experience with this rare, but often fatal, complication of liver transplantation are reviewed. In contrast to GVHD after bone marrow transplantation, pancytopenia is com- mon and liver dysfunction is rare. One should have a high level of suspicion in the liver transplant recipient presenting with rash and/or diarrhea.

Key Words: Aspergillosis; Cytomegalovirus; Esophagitis; Graftversus-host disease; Immunosuppression; Liver; Myocarditis; Primary biliary cirrhosis; Skin disease

\section{Réaction du greffon contre l'hôte après transplantation hépatique compliquée par une aspergillose systémique et une pancardite}

RÉSUMÉ : La réaction aiguë du greffon contre l'hôte est une complication courante après la transplantation de moelle osseuse, qui se manifeste typiquement par des éruptions cutanées et de la diarrhée. Après la transplantation hépatique, par contre, ce phénomène est très rare. La plupart des receveurs de transplantation prennent divers médicaments dont des immunosuppresseurs. Le diagnostic différentiel des éruptions cutanées ou de la diarrhée est donc vaste. On présente ici le cas d'un homme de 37 ans qui a subi une transplantation hépatique pour cirrhose biliaire primaire et qui a développé une éruption cutanée et de la diarrhée. Les biopsies cutanées et coloniques ont confirmé une réaction aiguë du greffon contre l'hôte. Des corticostéroïdes par voie intraveineuse ont été administrés en bolus. L'éruption cutanée s'est améliorée, mais le patient a développé une pancytopénie. Son état s'est compliqué d'une infection de son cathéter central, d'une thrombose veineuse jugulaire et sous-clavière, d'une colite

voir page suivante

This paper was a winning entry in the 'Consults in Gastroenterology' Case Study Competition, which was initiated and funded with the generous sponsorship of Astra Canada and is endorsed by the Canadian Association of Gastroenterology

${ }^{1}$ WC Mackenzie Health Sciences Centre, Department of Medicine, Division of Gastroenterology; ${ }^{2}$ Department of Pathology; ${ }^{3}$ Department of Surgery, University of Alberta, Edmonton, Alberta

Correspondence and reprints: Dr J Romagnuolo, Internal Medicine and Gastroenterology, Graduate Studies in Biostatistics and Epidemiology, McGill University/Montreal General Hospital, 1650 Cedar D7-148, Montreal, Quebec H3G 1A4. Telephone 514-937-6011 ext 3902, fax 514-934-8375, e-mail jromag@po-box.mcgill.ca 
pseudo-membraneuse, d'une bactériémie récurrente, d'une cholostase liée à la nutrition parentérale totale et d'une infection à cytomégalovirus. Après le déclenchement d'une douleur thoracique d'origine pleurale et d'une septicémie clinique, une tomodensitométrie spiralée du thorax et de l'abdomen ont révélé des infarctus septiques affectant de multiples organes. Malgré un traitement empirique à l'amphotéricine $B$, le patient est décédé d'une défaillance pluri-organique dans les 72 heures. L'autopsie a révélé une aspergillose systémique avec pancardite, végétations endocardi- ques et infarctus septique au niveau du poumon, de la rate, du foie et de du rein. La pathogenèse et les manifestations de cette complication rare, mais souvent fatale, de la transplantation hépatique sont passées en revue. Comparativement à la réaction du greffon contre l'hôte qui suit la transplantation de moelle osseuse, la pancytopénie est courante et la dysfonction hépatique est rare. Il faudrait donc entretenir un fort degré de suspicion face à un receveur de transplantation hépatique qui présente une éruption cutanée et (ou) de la diarrhée.
G raft-versus-host disease (GVHD) is a common complication of bone marrow transplantation (BMT) and involves donor lymphocytes attacking the host and leading to a constellation of symptoms and signs, including diarrhea, skin rash and elevated liver function tests. After orthotopic liver transplantation (OLT), however, this phenomenon is quite rare, has a slightly different presentation and is associated with a high sepsis-related mortality. Immunosuppression of the host is an important prerequisite for GVHD; however, further immunosuppression is the standard approach, in hopes of suppressing or destroying the donor lymphocytes out of proportion to those of the host. The following case outlines the presentation, treatment and approach of complications in a liver transplant recipient with GVHD.

\section{CASE PRESENTATION}

A 37-year-old married man with primary biliary cirrhosis, hypercholesterolemia and type II diabetes mellitus presented with a one-week history of skin rash and diarrhea 23 days after having undergone OLT. The rash was a pruritic, symmetrical, erythematous, maculopapular skin eruption on his neck, back and chest, with prominent involvement of his palms and soles. The rash was perifollicular, and there were some coalescing patches of erythema and target lesions. As well, he complained of three days of large-volume, watery, nonbloody diarrhea with urgency and tenesmus, but denied having fever, abdominal pain or nausea. His other medications included ranitidine, insulin, prednisone $20 \mathrm{mg}$ orally once daily, and cyclosporine $375 \mathrm{mg}$ orally bid, with an admission trough level of $470 \mathrm{~g} / \mathrm{L}$. In addition, he had been enrolled in a double-blinded study receiving either placebo or basiliximab, a chimeric (mouse/human) anti-interleukin (IL) -2 receptor monoclonal antibody.

The OLT surgery went without complication (Table 1). Methylprednisolone $100 \mathrm{mg}$ intravenously bid, cyclosporine $7.5 \mathrm{mg} / \mathrm{kg} /$ day orally, and the oral study drug were given postoperatively. No azathioprine was used. He was started on trimethoprim-sulphamethoxazole for pneumocystis prophylaxis.

A skin punch biopsy was consistent with GVHD. His creatinine level was $410 \mathrm{~mol} / \mathrm{L}$ and fell to $144 \mathrm{~mol} / \mathrm{L}$ with intravenous fluids. Sigmoidoscopy and gastroscopy revealed $30 \mathrm{~cm}$ of severe colitis with multiple shallow ulcers, ulcerative esophagitis, gastritis and duodenitis. All biopsies revealed evidence of acute GVHD, with apoptosis and glandular dropout (Figure 1). Repeated human leukocyte an-
Table 1

Selected relevant details concerning the transplantation surgery, the donor and the recipient

\begin{tabular}{|c|c|c|}
\hline Estimated blood loss & \multicolumn{2}{|c|}{$500 \mathrm{~cm}^{3}$} \\
\hline Cold ischemic time & \multicolumn{2}{|c|}{$8 \mathrm{~h}, 48 \mathrm{mins}$} \\
\hline $\begin{array}{l}\text { Gross/histology of } \\
\text { recipient's liver }\end{array}$ & \multicolumn{2}{|c|}{ Precirrhotic } \\
\hline \multirow{2}{*}{$\begin{array}{l}\text { Lymphocytotoxic } \\
\text { antibody screen }\end{array}$} & \multicolumn{2}{|c|}{ Positive, $7 / 27$} \\
\hline & Donor & Recipient \\
\hline CMV status & Positive & Positive \\
\hline EBV status & Negative & Positive \\
\hline ABO-Rh blood group & $\mathrm{A}+$ & $\mathrm{A}+$ \\
\hline HLA typing & $\begin{array}{c}\mathrm{A} 3,11 ; \mathrm{B} 8 ; \mathrm{C} 18 ; \mathrm{DR} 18 ; \\
\text { DQ2 }\end{array}$ & $\mathrm{A} 2,3 ; \mathrm{B} 18,60 ; \mathrm{C} 3,7$ \\
\hline
\end{tabular}

CMV Cytomegalovirus; EBV Epstein-Barr virus; HLA Human leukocyte antigen

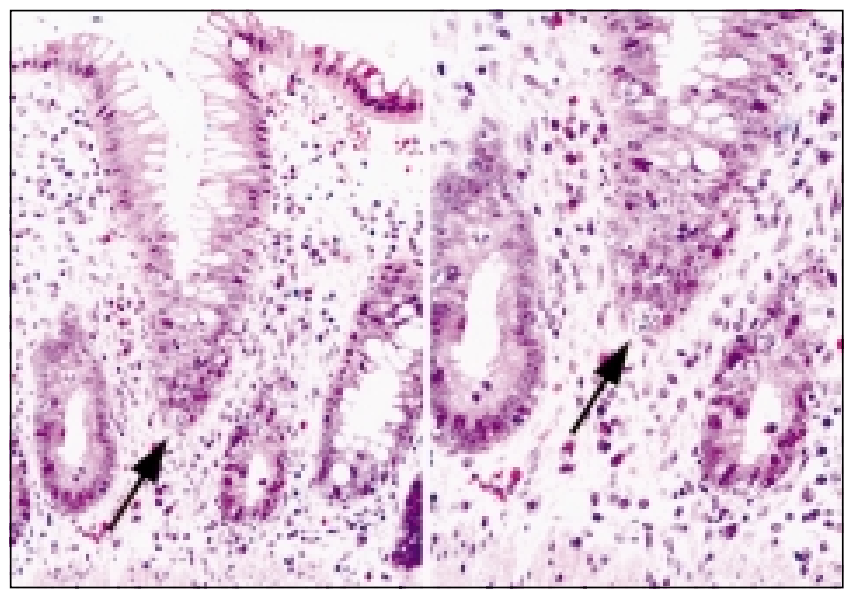

Figure 1) Left Biopsy of the colon showing acute graft-versus-host disease with several examples of apoptotic bodies (arrow) (hematoxylin and eosin stain, original magnification $\times 220$ ). Right A higher magnification of the field shown on the left. (hematoxylin and eosin stain, original magnification $\times 350$ )

tigen (HLA) typing did not reveal chimerism. Cytomegalovirus (CMV) buffy coat, stool cultures and Clostridium difficile toxin assays were negative. The prednisone dose was increased to $60 \mathrm{mg} / \mathrm{day}$.

After one week, he developed thrombocytopenia $\left(62 \times 10^{9} / \mathrm{L}\right)$, and intravenous methylprednisolone sodium succinate $500 \mathrm{mg}$ was given daily and then slowly tapered. After an additional week, his rash improved but the diarrhea 


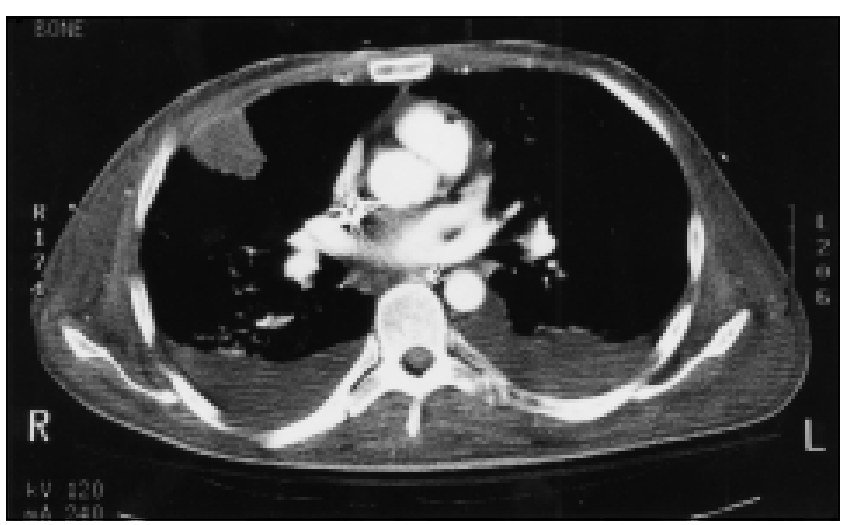

Figure 2) Spiral computed tomography chest scan showing a nonenhancing peripheral wedge-shaped region of increased attenuation in the right lung parenchyma consistent with pulmonary infarction from embolism

persisted. A dose of intravenous immunoglobulin was given. His course was complicated by pseudomembranous colitis, recurrent Gram-negative bacteremia, jugular/subclavian vein thrombosis related to line infection, CMV disease, severe pancytopenia (requiring platelets and granulocyte colony-stimulating factor) and cholestasis (total parenteral nutrition-related).

Forty-two days after admission, as he began to improve, he started having brief episodes of pleuritic right-sided chest pain without shortness of breath. A chest $\mathrm{x}$-ray revealed an infiltrate below the right hilum and small nodular opacities peripherally in the left midlung zone. Lung biopsy could not be performed because of refractory thrombocytopenia. He quickly deteriorated and blood cultures grew Enterobacter species. With the suspicion of systemic aspergillosis, intravenous amphotericin B was begun and his cyclosporine was held. After an asystolic cardiac arrest, he was resuscitated and a pacemaker was inserted. He underwent an unrevealing bronchoscopy (no fungi, no pneumocystis), but a spiral computed tomography was consistent with multiple pulmonary emboli (Figure 2). Unfortunately, over the next $12 \mathrm{~h}$, he became pacemaker- and inotrope-dependent, his white blood cell count was $55 \times 10^{9} / \mathrm{L}$, his lactate level was $25 \mathrm{mmol} / \mathrm{L}$ and he was anuric on continuous venous-venous hemodialysis. Supports were withdrawn.

Autopsy revealed severe aspergillus pancarditis with transmural, widespread necrosis (Figure 3), fibrinous pericarditis, infective (aspergillus) endocarditis with vegetations on the left and right atrial endocardium, and probable septic emboli with renal and splenic infarcts. There was evidence of angioinvasive pulmonary aspergillosis with infarction (Figure 3).

\section{DISCUSSION}

Although the clinical presentations of acute GVHD in OLT and BMT are similar, there are important differences. In BMT, symptoms usually include diarrhea, liver dysfunction and skin rash. The classic rash is characterized by erythroderma of the palms, soles and ears; truncal perifollicular ery-

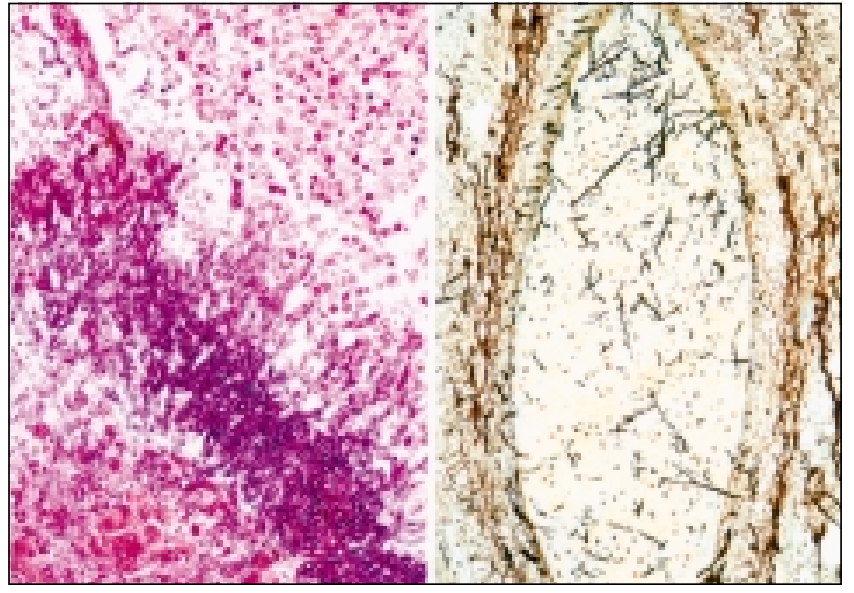

Figure 3) Left Autopsy specimen of lung tissue showing aspergillus with pulmonary necrosis and alveolar edema (hematoxylin and eosin stain, original magnification $\times 220$ ). Right Autopsy specimen of heart tissue showing aspergillus myocarditis with invasion of a myocardial vessel. (Gomori's methanamine silver stain, original magnification $\times 350$ )

thema; targets; and rarely bullae. Fever is sometimes present. Chimerism may be demonstrated often with HLA typing. Sanchez-Izqierdo et al (1) reviewed the English language medical literature in 1996 and found 13 cases of acute GVHD after OLT. There were notable differences when compared with BMT: frequent pancytopenia; early presentation (two to six weeks); and absence of liver involvement. The latter feature presumably is due to the recognition of the liver as 'self' by the alloreactive lymphocytes (perhaps why pancytopenia usually does not follow BMT). Among the 13 patients (1-10), three were women, four had previously rejected transplants - two of whom had been given antithymocyte globulin (ATG) - and $10(76.9 \%)$ patients died (of sepsis in all cases in which cause of death was specified). Disseminated candidiasis occurred in three cases, but aspergillosis was not reported. Only one other case of aspergillus endocarditis complicating OLT was reported in the literature (11). Five further cases of acute GVHD after OLT have been published, two of which were pediatric cases (12-16).

Billingham (17) described the phenomenon of acute GVHD as requiring the following: graft containing immunologically competent cells; alloantigens in the host that are foreign to the donor; and incapability of the host to mount an effective immune response against the graft.

Histologically, the hallmark of acute GVHD is apoptosis with selective epithelial damage. Particularly, cells that are undifferentiated, and perhaps bear more primitive surface antigens, are targeted (tips of the skin's rete ridges, the hepatic periductular epithelium, the bases of intestinal crypts) (18).

Lymphocyte migration and mixed chimerism occur in successful organ transplantation, but why some patients develop GVHD is unknown. The process seems to have two phases (18). The afferent phase consists of antigen presentation, IL-1 production, T cell activation involving IL-2, and clonal proliferation and differentiation. The efferent phase is not well understood. There is either direct cytotoxicity or in- 
direct cytolysis via intermediaries such as tumour necrosis factor (TNF). Donor HLA homozygosity (1\% to $2 \%$ of the population), when the recipient shares a haplotype, may play a role in living-related, pediatric OLT.

Interferon-gamma, TNF- , IL-1, IL-2 and other cytokines may increase major histocompatability complex expression in the recipient and upregulation of adhesion molecules, which in turn increases alloreactive $T$ cells' recognition of host-donor differences (19). In this way, infections, through cytokine release, may perpetuate or trigger GVHD. GVHD does not occur in gnotobiotic (germ-free) mice.

Timing of immunomodulation appears to be crucial. IL-2 given immediately to mice after transplantation decreased mortality from BMT-related GVHD by about $70 \%$. However, when the same cytokine was given one week later, it was able to trigger GVHD (20). An IL-2 receptor blocker, such as basiliximab, although an effective treatment for GVHD, once it has begun, could potentially increase the risk of GVHD if given immediately after transplantation.

Increased immunosuppression is the treatment of choice with the intention of suppressing the alloreactive lymphocytes from the donor (19). However, both donor and recipient systems are affected, leading to the high mortality attributable to infection and to the poor success. High-dose steroids prevent IL-1 production and are lympholytic. Although cyclosporine can cause GVHD in syngeneic murine BMT through thymic effects, it can be an effective treatment for allogeneic GVHD, via the inhibition of IL-2 production and IL-2 receptor expression (21). The mechanism by which intravenous immunoglobulins cause immunosuppression

\section{REFERENCES}

1. Sanchez-Izquierdo JA, Lumbreras C, Colina F, et al. Severe graft versus host disease following liver transplantation confirmed by PCRHLA-B sequencing: report of a case and literature review. Hepatogastroenterology 1996;43:1057-61.

2. Roberts JP, Ascher NL, Lake J, et al. Graft vs host disease after liver transplantation in humans: a report of four cases. Hepatology 1991;14:274-81.

3. Burdick JF, Vogelsang GB, Smith WJ, et al. Severe graft-versus-host disease in a liver-transplant recepient. N Engl J Med 1988;318:689-91.

4. Jamiesen NV, Joysey V, Friend PJ, et al. Graft-versus-host disease in solid organ transplantation. Transplant Int 1991;4:67-71.

5. Collins RH Jr, Cooper B, Nikaein A, Klintmalm G, Fay JW. Graftversus-host disease in a liver transplant recipient. Ann Intern Med 1992;116:391-2.

6. DePaoli AM, Bitran J. Graft-versus-host disease and liver transplantation. Ann Intern Med 1992;117:170-1.

7. Marubayashi S, Matsuzaka C, Takeda A, et al. Fatal generalized acute graft-versus-host disease in a liver transplant recipient. Transplantation 1990;50:709-11.

8. Rosen CB, Ng CS, Moore SB, et al. Clinical and pathological features of graft-versus-host disease after liver transplantation: a case report and review of the literature. Clin Transplant 1993;7:52-8.

9. Redondo P, Espana A, Herrero JI, et al. Graft-versus-host disease after liver transplantation. J Am Acad Dermatol 1993;29:314-7.

10. Mazzaferro V, Andreola S, Regalia E, et al. Confirmation of graftversus-host disease after liver transplantation by PCR HLA-typing. Transplantation 1993;55:423-5.

11. Woods GL, Wood RP, Shaw BW Jr. Aspergillus endocarditis in patients without prior cardiovascular surgery: report of a case in a liver transplant recipient and review. Rev Infect Dis 1989;11:263-72. probably involves the binding of the Fc portion to natural killer cells, which targets them for elimination while preventing recognition of target tissue. Other lymphocytotoxic agents, including antilymphocyte globulin and ATG or OKT3, are used in a stepwise manner. Antifungal coverage and aggressive infection surveillance are paramount. Prophylactic measures such as immunosuppression of the donor, pretransplant perfusion of the graft with antilymphoblast globulin, organ irradiation or physical removal of nodal tissue from the donor liver hardly are justified for all OLT, given the rarity of GVHD. Also, eliminating all donor lymphoid cells usually decreases tolerance and leads to more rejection. Potentially, there may be less graft-versus-tumour effect when transplantation has been performed for neoplasia, as has been shown in BMT.

Acute GVHD is an unusual complication of liver transplantation but one with a high fatality rate. It should be suspected in any OLT patient presenting with pancytopenia, diarrhea and/or rash. Our patient had prompt attention to various infections and limited exposure to anaerobic antibiotics (risk factors for fungal infection). In addition, fluconazole was given prophylactically. Despite these measures, he still succumbed to disseminated aspergillosis; therefore, lowdose, amphotericin B prophylaxis should be considered when high-dose steroids are initiated for GVHD.

ACKNOWLEDGEMENT: We thank Astra Canada for their generous support of this initiative.

12. Reyes J, Todo S, Green M, et al. Graft-versus-host disease after liver and small bowel transplantation in a child. Clin Transplant 1997;11:345-8.

13. Neuman U, Knoop M, Langrehr JM, et al. [Graft-vs.-host reaction: a severe complication after orthotopic liver transplantation]. Zentralblatt für Chirurgie 1995;120:478-81.

14. Whitington PF, Rubin CM, Alonso EM, et al. Complete lymphoid chimerism and chronic graft-versus-host disease in an infant recipient of a hepatic allograft from an HLA-homozygous parental living donor. Transplantation 1996;62:1516-9.

15. Pageaux GP, Perrigault PF, Fabre JM, et al. Lethal acute graft-versushost disease in a liver transplant recipient: relations with cell migration and chimerism. Clin Transplant 1995;9:65-9.

16. Burt M, Jazwinska E, Lynch S, et al. Detection of circulating donor deoxyribonucleic acid by microsatellite analysis in a liver transplant recipient. Liver Transpl Surg 1996;2:391-4.

17. Billingham RE. The biology of graft-versus-host reactions. Harvey Lect 1966;62:21-78.

18. Ferrara JL, Deeg HJ. Graft-versus-host disease. N Engl J Med 1991;324:667-4.

19. Vogelsang GB, Hess AD. Graft-versus-host disease: new directions for a persistent problem. Blood 1994;84:2061-7.

20. Sykes M, Romick ML, Hoyles KA, Sachs DH. In vivo administration of interleukin 2 plus $T$ cell-depleted syngeneic marrow prevents graftversus-host disease and permits alloengraftment. J Exp Med 1990;171:645-58.

21. Storb R, Deeg HJ, Whitehead J, et al. Methotrexate and cyclosporine compared with cyclosporine alone for prophylaxis of acute graft versus host disease after marrow transplantation for leukemia. N Engl J Med $1986 ; 314: 729-35$ 


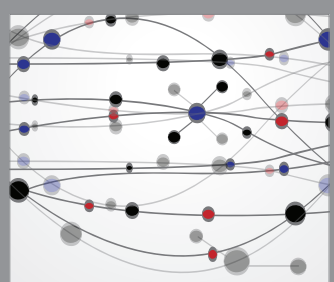

The Scientific World Journal
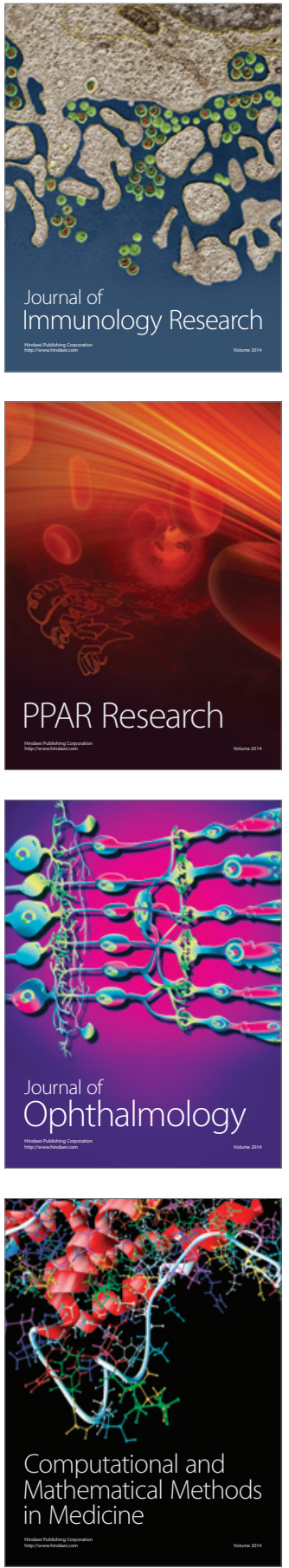

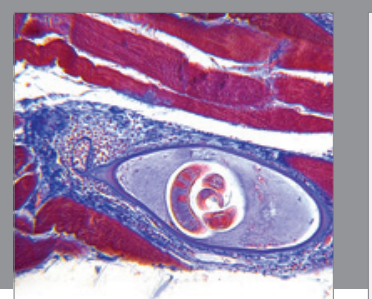

Gastroenterology Research and Practice

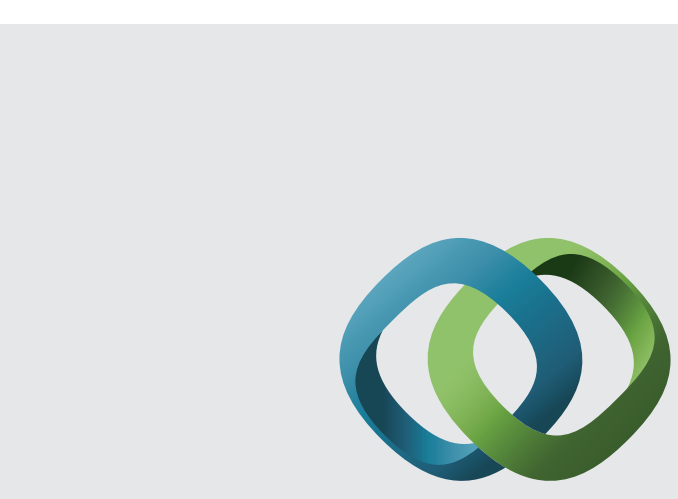

\section{Hindawi}

Submit your manuscripts at

http://www.hindawi.com
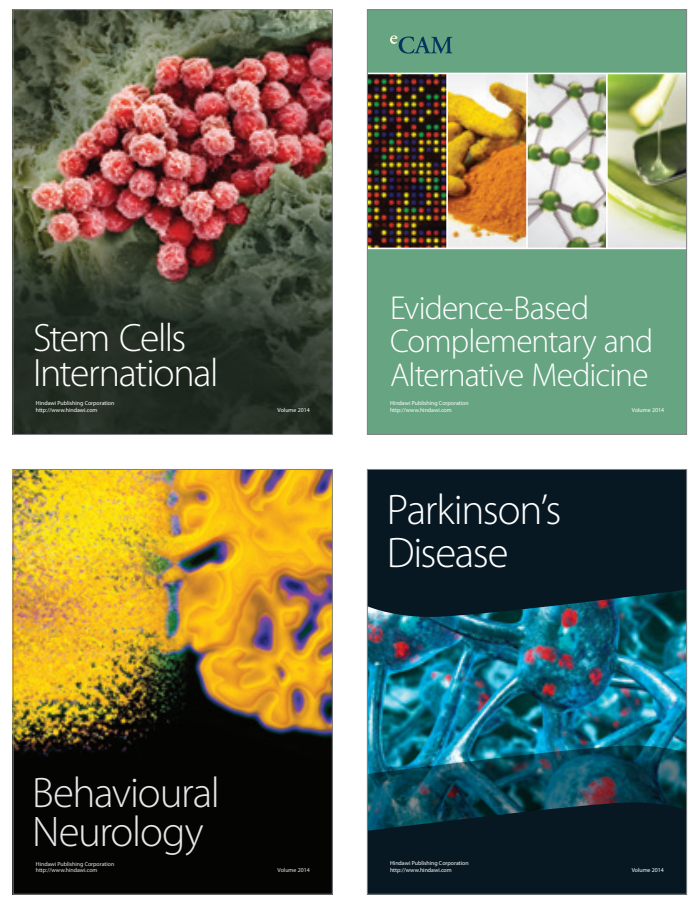
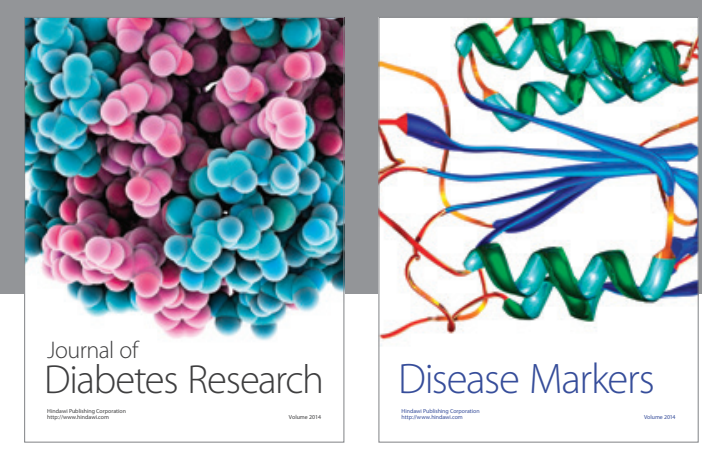

Disease Markers
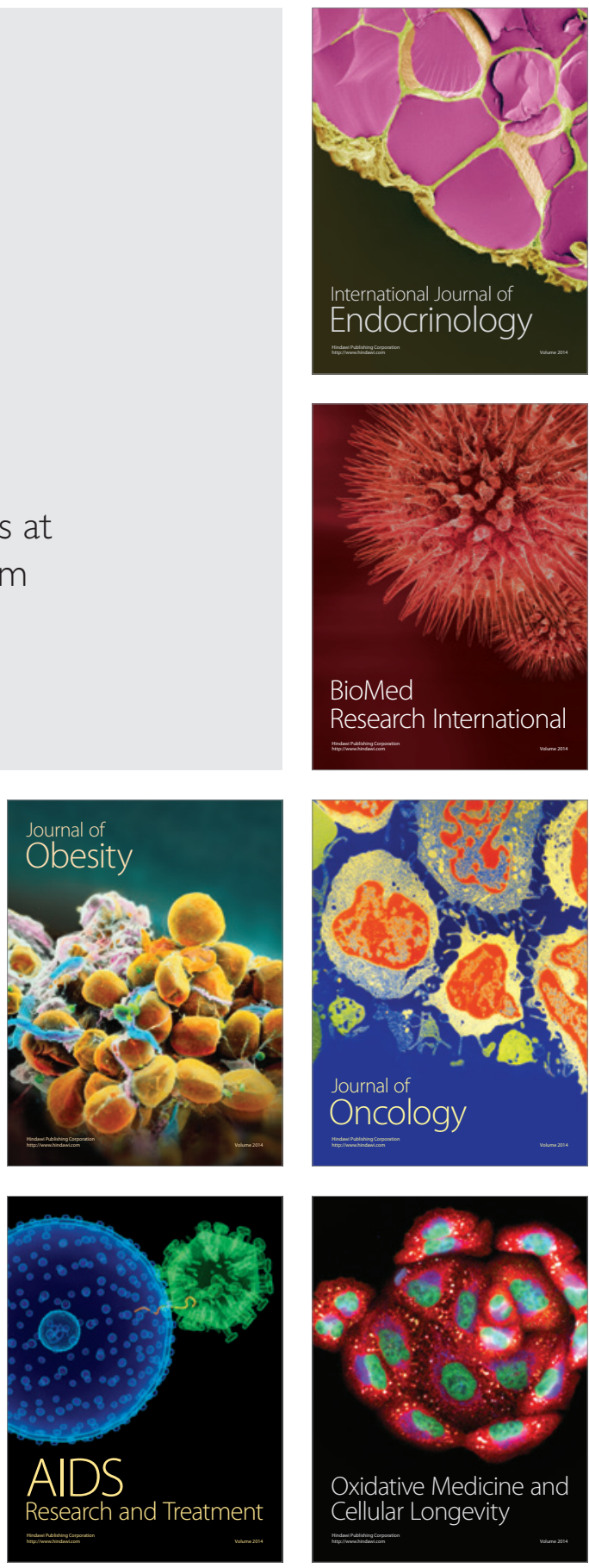